\title{
Effects of Coffee Bean Grounds on Urochloa brizantha Growth
}

\author{
Tácio P. Da Silva ${ }^{1}$, Bruno M. R. de Melo ${ }^{2}$, Douglas G. Castro ${ }^{1}$, Antonio R. Neto ${ }^{1}$, \\ Marco R. Félix ${ }^{1} \&$ Flávia B. S. Botelho ${ }^{1}$ \\ ${ }^{1}$ Agriculturl Departament, Federal University of Lavras, Lavras, Minas Gerais State, Brazil \\ ${ }^{2}$ Federal Institude of Education, Science and Technology of South of Minas Gerais, Inconfidentes Campus, \\ Inconfidentes, Minas Gerais State, Brazil \\ Correspondence: Douglas Goulart Castro, Agricultural Department, Federal University of Lavras, Lavras, Minas \\ Gerais, Brazil. Tel: 55-359-9153-8018. E-mail: douglasgoulartcastro@gmail.com
}

Received: October 28, 2018

Accepted: December 7, 2018 Online Published: February 15, 2019

doi:10.5539/jas.v11n3p381

URL: https://doi.org/10.5539/jas.v11n3p381

\begin{abstract}
The management of invasive plants is strategic for agricultural areas, since these plants lead to a reduction in productivity. Among potential forms of management is the application of coffee grounds, given that the caffeine present in this residue has allelopathic effects. As such, this study's objective was to evaluate Urochloa brizantha growth and phytotoxicity when administering different doses of coffee grounds before and after emergence. The experiment was conducted in a greenhouse of the Federal University of Lavras. Planting of the invasive species employed 8-liter vases with 50 seeds each. Assays were performed using a randomized block design, with three replicates, in a $4 \times 2$ factorial scheme. The first factor was coffee ground dosage: 55, 73 and $100 \mathrm{~g}$ doses were diluted in $100 \mathrm{~mL}$ of water, and each pot received $100 \mathrm{~mL}$ of coffee grounds slurry. The second factor was period of application: pre or post-emergence. Evaluated parameters were: plant height; dry shoot mass; phytotoxicity, speed of emergence (SE), and number of emerged plants. We found that pre-emergence treatments significantly reduced the growth of Urochloa brizantha. In respect to the 'SE' and 'number of emerged plants' parameters, slurry with coffee grounds doses up to $50 \mathrm{~g}$ were found to compromise plant emergence. In respect to phytotoxicity percentage, a linear increase was observed according to the increase in sludge dosage. This study concludes that, when applied during pre-emergence and in low concentrations, coffee grounds compromise the growth of Urochloa brizantha.
\end{abstract}

Keywords: organic waste, allelopathic, weeds, phytotoxicity

\section{Introduction}

As one of the largest contributors to gross domestic product, Brazilian agriculture has shown satisfactory performance over the years. It is a diversified agriculture, given the continental dimensions of the country and its cultural differences., However, irrespective of region, one of the prevalent factors of damaged crops is the occurrence of weeds, which competes with agricultural crops for water, light, space, and nutrients (Vasconcelos et al., 2012), besides making it difficult to harvest grains.

Weed is conceptualized in several ways, being the one that presents more practical context, when its occurrence is in undesired place. Among the weeds that occur along with the agricultural crops we highlight Urochloa spp. These plants, when not properly managed, present a great capacity of competition with the agricultural crop, mainly with the crops of group $\mathrm{C} 3$.

For the sustainable management of Urochloa spp. it is necessary to associate several control practices that aim to diminish its competitive effect with cultivated plants. This entails the reduction of costs and the use of strategies to minimize the impact of pesticides on the environment through an approach that aims to reduce the resistance of weeds to the application of herbicides of the same chemical group, adding an opportunity to manage these for farmers who do not use agricultural pesticides on crops.

Coffee grounds us the residue of coffee preparation that remains after water is boiled and infused with coffee powder. In its composition it has caffeine, chemically known as 1,3,7-trimethylxanthine, with a $\mathrm{C} / \mathrm{N}$ ratio of 22/1 and a nitrogen concentration of 2.3\% (Nogal et al., 2005; Mussato et al., 2011), which according to these authors can have an allelopathic effect on cultivated species, either by inhibiting seed germination or seedling growth (Chou \& Waller, 1980). 
Coffee grounds has 0.02 to $0.08 \%$ caffeine (Fan \& Soccol, 2005), and its composition variates according to the different blends and the quantity of each species of coffee contained in the powder mixture (Torres et al., 2012).

A suggested hypothesis for the allelopathic effect of the sludge refers to the fact that this in nature material needs to be decomposed, otherwise damaging the plants, given the high microbiological activity involved in the decomposition process (Kiehl, 2010).

According to Friedman, Waller (1983), this substance causes a reduction of invasive plants around the coffee plant, possibly associated with caffeine washing of the canopy. However, its use must be controlled, considering the material has organic and inorganic compounds that can be environmental pollutants (Mussato et al., 2011).

Cruz (2015), while experimenting with the application of coffee grounds, observed a decrease in lettuce, carrot and spinach growth, revealing that the inhibition of $\mathrm{N}$ and $\mathrm{P}$ mineralization reduced plant growth, which also may be associated with the presence of caffeine.

Therefore, the objective of this study was to evaluate the growth and phytotoxicity of Urochloa brizantha after application of coffee grounds, pre and post-emergence.

\section{Material and Methods}

\subsection{Experiment Location}

The experiment was conducted in greenhouse at the Federal University of Lavras (UFLA), in the Department of Agriculture, located at the following geographical coordinates: Latitude $21^{\circ} 14^{\prime} \mathrm{S}$, Longitude $45^{\circ} 00^{\prime} \mathrm{W}$, and average altitude of 920 meters. The climatic classification for Lavras is Cwa, temperate and rainy with a temperature of $22^{\circ} \mathrm{C}\left(22.1{ }^{\circ} \mathrm{C}\right.$ in February) (Dantas et al., 2007).

Sowing of the weed was carried out in October 2017, using 8 liter pots, which were filled with soil Dystroferric Red Latosol. Fifty seeds of Urochloa brizantha cultivar BRS Piatã were sown in each pot, with a $75 \%$ pure live seed (PLS) rate, in five rows with 10 seeds each, at a depth of $2 \mathrm{~cm}$. This species is an erect growth plant that forms clumps, with leaves up to $45 \mathrm{~cm}$ in length. Although they have no pilosity, the leaves' upper part is rough and sharp-edged. The plant is perennial, with an, average size and height between 0.85 and $1.10 \mathrm{~m}$.

\subsection{Experiment Installation}

Sowing of the Urochloa occurred 21 days after the pots were filled with soil. The pots were kept in a greenhouse under irrigation, so that the seed bank in the soil could emerge and then be withdrawn. Irrigation was performed using micro-nebulizers. The experiment was carried out using randomized block design (RBD), with three replicates and a $4 \times 2$ factorial. The first factor was coffee sludge concentration: 55,73 or $100 \mathrm{~g}$ of coffee grounds and a control treatment with no coffee grounds, i.e., pure water application. The different dosages of coffee grounds were diluted in $100 \mathrm{~mL}$ of water and a volume of $100 \mathrm{~mL}$ of coffee grounds slurry was applied per pot, using a wash bottle. The second factor was the period of application: pre- or post-emergence. The experiment was comprised of 8 distinct treatments and 24 experimental plots.

The coffee grounds were collected from the UFLA cafeteria and, kept at room temperature. Pre-emergence applications, took place one day after sowing, while post-emergence applications occurred 45 days after sowing. The coffee grounds were collected one day before application. The solute and solvent were mixed for one minute, using a blender. As previously noted, $100 \mathrm{~mL}$ of the solution was applied to each plot.

\subsection{Parameters Assessment}

Evaluated parameters were: plant height 60 days after sowing (five plants per plot assessed, using a millimeter ruler); dry mass of the aerial part, carried out in a forced circulation air oven at $60{ }^{\circ} \mathrm{C}$ until reaching constant weight (weighing done on a precision scale); visual analysis of phytotoxicity using a grade scale from 0 (no damage) to 100 (total destruction) (Rolim, 1989) (carried out by three people, from the average of the evaluators' scores); speed of germination index (SGI) according to Maguire's (1962) methodology (measuring carried out until the seedlings reached germination stability); index of germinated plants, calculated after the seed bank stabilized.

$$
S G I=\left(N_{1}+N_{2}+\ldots+N_{n}\right) /\left(D_{1}+D_{2}+\ldots+D_{n}\right)
$$

Where, $\mathrm{SGI}=$ speed of germination index; $\mathrm{N}=$ number of seedlings count; $\mathrm{D}=$ numbers of days after sowing when the counting was performed.

\subsection{Statistical Analysis}

For each parameter evaluated in respect to each treatment, analysis of variance and comparison of means (Tukey test at $5 \%$ of probability) were performed (qualitative analyzes). Polynomial models were used to assess the 
effect of input doses (quantitative analyzes). The criterion for model choice was the level of significance (F test at $5 \%$ probability of error) that presented the highest coefficient of determination (r2). Statistical analysis was performed in the Sisvar software (Ferreira, 2011).

\section{Results}

No interaction was verified for any of the studied factors. Table 1 shows that the pre-emergence treatments resulted in the reduction of emergence, dry weight and height of the plants, demonstrating the slurry's behavior during pre-emergence and post-initial emergence, given that residues of the slurry were seen over the soil during the first ten days after application.

The percentage of phytotoxicity increased along with slurry dosages (Figure 1) (p-value 0.0001). The slurry probably has a prolonged residual effect, which would explain the observation Table 1 -Speed of germination index (SGI), dry weight and height of Urochloa brizantha resulting frompre and post-emergence slurryapplications.

Table 1. Speed of germination index (SGI), dry weight and height of Urochloa brizantha resulting from pre and post-emergence slurry applications

\begin{tabular}{llll}
\hline Treatment & SGI & Dry weight & Height \\
\hline Pre-emergency & $3.12 \mathrm{a}$ & $1.20 \mathrm{a}$ & $7.54 \mathrm{a}$ \\
Post-emergence & $3.41 \mathrm{~b}$ & $1.52 \mathrm{~b}$ & $8.92 \mathrm{~b}$ \\
\hline PLS (\%) & 9.84 & 15.13 & 14.41 \\
\hline
\end{tabular}

Note. Averages followed by the same letter in the column do not differ statistically from one another (at $5 \%$ probability).

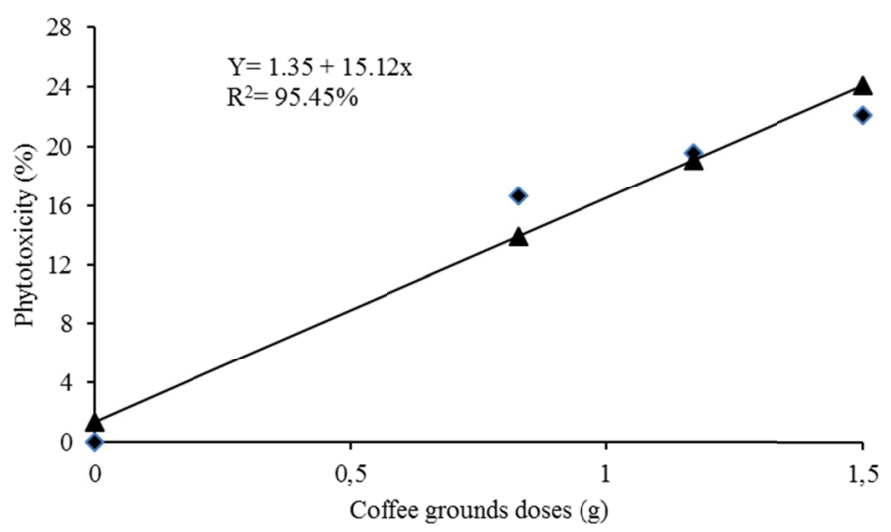

Figure 1. Phytotoxicity of Urochloa brizantha as a function of coffee grounds dosage. Lavras, 2018

There were reductions of SGI and number of emerged plants at low residue concentrations, with a maximum inhibition dose of $0.76 \mathrm{~kg}$ (p-value 0.023 ) and $0.75 \mathrm{~kg}$ (p-value 0.004 ) (Figure 2). Figure 2 shows the behavior of seedsand seedlings. 

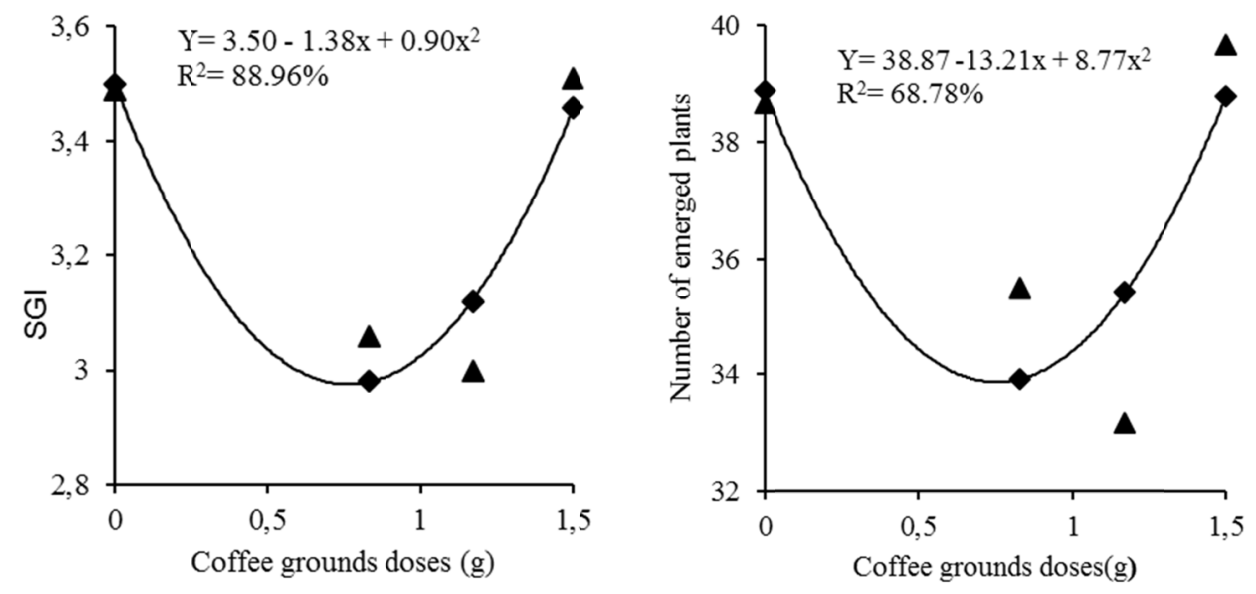

Figure 2. Speed of germination index (A) and number of emerged plants (B) of Urochloa brizantha as a function of coffee grounds dosage. Lavras, 2018

\section{Discussion}

Verifiably, the residue is better assimilatedatthe seed stage, provoking cytotoxic effectsthat inducenuclear alterations and the binucleation of the meristematic cells (Ferreira, 2011) reducing the SGI (Table 1). However, the residue can have deleterious effects when the plants are in the seedling stage, since these are more sensitive to environmental stress,

Waller et al. (1986) describe caffeine as a powerful growth inhibitor which may accumulate in the soil near andaround coffee plants; it is phytotoxic (Figure 1) to the radicles of young coffee plants themselves, thushelping to control invasive species in coffee plantations also.

Cruz (2015), working with the application of coffee grounds, observed a decrease in lettuce, carrot and spinach growth, noting that inhibition of $\mathrm{N}$ and $\mathrm{P}$ mineralization also had an inhibitory effect on plant growth. Theauthor also states that results in the literature are still contradictory, but the main reason for such inhibition may be related to caffeine, which may have reduced the availability of nitrogen to the plants during the process of mineralization and immobilization.

May et al. (2011) concluded that the aqueous extract of the coffee straw contains caffeine, whose residue inhibited development of evaluated plants. The author points out that coffee straw extract interfered with plant growth, forming abnormal seedlings with greater root sensitivity, leading tonecrosis and anomalies such as thickening and curling. Thispartially explains the twisting and bending of Urochloa brizantha seedlings as result of pre-emergence applications.

Torres et al. (2012), working with coffee seeds sown in a substrate containing coffee grounds verified less emergence of seedlings. When emergence occurred it was slower than in the control, corroborating our results in the emergence of seedlings.

Theinflection of the curve with increasing doses of slurry seen in, Figure 2, may be associated with compoundsthat inhibit the effects of caffeine at higher residue concentrations. Minassa (2014) points out that the decrease in germination inhibition with the increase in slurry concentration suggests that extracts with low concentrationof Arabica coffee could have other substancesthat stimulate germination. The same author highlights that Arabica coffee straw extract in concentrations of 25 and $50 \%(\mathrm{v} / \mathrm{v})$ had a greater inhibitory effect on germination, whereas at a concentration of $100 \%(\mathrm{v} / \mathrm{v})$ it favored germination.

Marques (1992) observed that substances usually considered inhibitory to germination have the opposite effect when in small concentrations, with these otherwiseinhibiting substancesseeminglyacting on the enzymatic and other physiological activities of the plant. In the same way, Andrade (2009) verified that, in post-emergence tests with dichloromethane extract from coffee grounds, the inhibition of root growth was higher atsmaller, 50 and $100 \mu \mathrm{g} \mathrm{mL}{ }^{-1}$ concentrations, and that at a concentration of $200 \mu \mathrm{g} \mathrm{mL} \mathrm{L}^{-1}$ there was a lower percentage of inhibition.

By testing the allelopathic activity of coffee husk and coffee grounds extracts, Andrade (2009) concluded that these had significant inhibitory effects over root and shoot growth of Panicum maximum. The same author 
observed that coffee grounds contained caffeine almost exclusively, which couldhave contributed to the non-germination of the grass colonies.

It is noteworthy that, regardless of the coffee grounds dosage, this residue interfered with the initial growth of the plants. Therefore, the in natura disposal of this material to aquatic bodies or otherecosystems can compromise plant emergence, aggravating environmental problems. Alarmingly, a $2257 \mathrm{ng} / \mathrm{l}^{-1}$ water a concentration of this compoundwas found in Porto Alegre city (Potrich, 2014).

\section{Conclusions}

The growth of Urochloa brizantha in terms of height and dry weight was compromised in preemergence applications of coffee grounds, with a possible residual effect after initial emergence. Lower doses of coffee grounds compromise the emergence of Urochloa brizantha seedlings. Plant phytotoxicity increases along withslurry dosages, possibly influenced by the residual effect of the slurry on the soil; phytotoxicity is therefore influenced by bothpre and post-emergence applications. The coffee grounds present potential for the control of Urochloa brizantha.

\section{Acknowledgements}

To the Federal Institude of Education, Science and Technology of South of Minas Gerais (IFSULDEMINAS), for conceding us a leave that made this study possible; to the Federal University of Lavras for the equipment used; and tothe Sementes do Oeste Paulista (SOESP $®$ ) company, for the donation of the seeds.

\section{References}

Andrade, A. P. S. (2009). Análise química e avaliação do potencial alelopático da casca do café (Coffea arábica). (Dissertação de Mestrado (Química), Universidade Federal de Uberlândia, Minas Gerais).

Chou, C. H., \& Waller, G. R. (1980). Possible allelopathic constituents of Coffea arabica L. J Chem Ecol, 6, 643-639. https://doi.org/10.1007/BF00987675

Cruz, S. A. F. (2015). Avaliação do potencial da borra de café fresca na mineralização do nitrogênio e do fósforo e em culturas hortícolas (67f., Dissertação (Engenharia do Ambiente), Instituto Superior de Agronomia, Lisboa).

Dantas, A. A. A., Carvalho, L. G., \& Ferreira, E. (2007). Classificação e tendências climáticas em Lavras, MG. Ciência e Agrotecnologia, 31(6), 1862-1866. https://doi.org/10.1590/S1413-70542007000600039

Fan, L., \& Soccol, C. (2005). Shiitake Bag Cultivation. Part, I Shiitake. Coffee Residues. Mushroom Grower's Handbook. Mushworld All, 2, 92-94.

Ferreira, A. D. (2011). Influência da borra de café no crescimento e nas propriedades químicas e biológicas de plantas de alface (Lactuca sativa L.) Instituto Politécnico de Bragança (115f., Dissertação (Qualidade e Segurança Alimentar), Escola Superior de Agrária, Lisboa).

Ferreira, D. F. (2011). Sisvar: A computer statistical analysis system. Ciência e Agrotecnologia, 35(6), 1039-1042. https://doi.org/10.1590/S1413-70542011000600001

Friedman, J., \& Waller, G. R. (1983). Seeds as allelopathic agents. Journal of Chemical Ecology, 9(8), 1107-1117. https://doi.org/10.1007/BF00982215

Kiehl, E. J. (2010). Novos fertilizantes orgânicos (p. 248). Piracicaba: Agronômica Ceres.

Maguire, J. D. (1962). Speed of germination-aid selection and evaluation for seedling emergence and vigor. CropScience, 2, 176-177. https://doi.org/10.2135/cropsci1962.0011183X000200020033x

Marques, M. A. (1992). Potencial alelopático de resíduos de caruru (Amaranthus viridis) incorporado em três tipos de solos, sobre a germinação e crescimento inicial do algodoeiro (Gossypium hirsutum) (125f., Dissertação (Mestrado em Solos e Nutrição de Plantas), Universidade Federal de Lavras, Lavras).

May, D., Rocha, L., Oliveira, C. M. R., \& Maranho, L. T. (2011). Efeito de extratos de casca de café (Coffea arabica L.) na germinação e crescimento de pepino (Cucumis sativus L.). Revista Brasileira de Biociências, 9, 180-186.

Minassa, E. M. C. (2014). Efeito alelopático da palha de café (Coffea canephora L. e Coffea arábica L.) sobre plantas cultivadas e espontâneas (93f., Tese de Doutorado em Produção Vegetal, Centro de Ciências e Tecnologias Agropecuárias da Universidade Estadual do Norte Fluminense Darcy Ribeiro). 
Mussatto, I. S., Machado, E. M. S., Martins, S., \& Teixeira, J. A. (2011). Production, composition and application of coffee and its industrial residues. Food and Bioprocess Technology, 4(5), 661-672. https://doi.org/10.1007/s11947-011-0565-z

Potrich, L. (2014). Degradação da cafeina por processos oxidativos avançados (36f., Trabalho de diplomação em Engenharia Química, Escola de Engenharia, Universidade Federal do Rio Grande do Sul).

Rolim, J. C. (1989). Proposta de utilização da escala European Weed Research Coouncil (EWRC) modificada em ensaios de campos com herbicidas (p. 3). Araras: IAA/PLANALSUCAR.

Torres, A. J., Bregagnoli, M., Monteiro, J. M. C., \& Carvalho, C. A. M. (2012). Emergência de plântulas de cafeeiro em substratos de borra de café. Revista Agrogeoambiental, 4(3), 1-7. https://doi.org/10.18406/ 2316-1817v4n32012472

Vasconcelos, M. C. C., Silva, A. F. A., \& Lima, R. S. (2012). Interferência de plantas daninhas sobre plantas cultivadas. Agropec. Cient. Semi-Árido, 8(1), 1-6.

Waller, G. R., Kumari, D., Friedman, J., Friedman, N., \& Chou, C. H. (1986). Caffeine autotoxicity in Coffea arabica L. In A. R. Putnam, \& C. S. E. Tang (Eds.), The Science of Allelopathy (pp. 243-269). New York, John Wiley.

\section{Copyrights}

Copyright for this article is retained by the author(s), with first publication rights granted to the journal.

This is an open-access article distributed under the terms and conditions of the Creative Commons Attribution license (http://creativecommons.org/licenses/by/4.0/). 